\title{
FIKIH MINORITAS: SUATU KAJIAN TEORETIS
}

\author{
Nurhayati \\ Fakultas Dakwah dan Komunikasi IAIN Sumatera Utara \\ Jl. Wuliem Iskandar Pasar V, Medan Estate, 20371 \\ E-mail: maf_lubis74@yahoo.com
}

\begin{abstract}
Fiqh for Minorities: a Theoretical Study. Fiqh for Minorities—which in Arabic is called Fiqh al-Aqaliyyâtis a figh model that maintains legal association of sharia and the dimensions of a particular community, namely minority Muslim communities in western countries. Figh for Minorities is a product of reinterpretation of the existing arguments on the basis of the benefit whichis the spirit of sharia. The designers of this fiqh are Taha Jabir al-'Alwani in his book, Toward a Fiqh for Minorities: Some Basic Reflection, and Yûsuf al-Qarâdawî in his book, Fî Fiqh al-Aqalliyât alMuslimah. Fiqh for Minorities originated from the accumulation of the concerns of Muslim minority communities in western countries when it should be doing something related to their religion. This fiqh is designed to provide guidance and a handle on the things that are prohibited and permissible for Muslim minorities living in western countries to carry out their obligations as a Muslim.
\end{abstract}

Keywords: fiqh, minority, sharia

\begin{abstract}
Abstrak: Fikib Minoritas: Suatu Kajian Teoretis. Fikih minoritas-yang dalam bahasa Arab disebut dengan Fiqh alAqalliyât_-merupakan model fikih yang memelihara keterkaitan hukum shar î dengan dimensi-dimensi suatu komunitas tertentu, yaitu masyarakat minoritas Muslim di Barat. Fikih minoritas adalah sebuah produk hasil reinterpretasi atas dalil-dalil atas dasar kemaslahatan yang memang menjadi spirit syariah. Penggagas fikih ini adalah Tâhâ Jâbir al- 'Alwânî dalam bukunya, Toward a Figh for Minorities: Some Basic Reflection dan Yûsuf al-Qarâdawî dalam bukunya, Fî Fiqh al-Aqalliyât al-Muslimah. Fikh minoritas lahir berawal dari akumulasi kegelisahan masyarakat minoritas Muslim di Barat ketika harus melakukan sesuatu yang berkaitan dengan keagamaan mereka. Fikih ini didesain untuk memberikan panduan dan pegangan tentang hal-hal yang dilarang dan yang boleh bagi minoritas Muslim yang tinggal di Barat untuk menjalankan kewajiban-kewajiban mereka sebagai seorang Muslim.
\end{abstract}

Kata Kunci: fikih, minoritas, syariah

\section{Pendahuluan}

Islam menganjurkan adanya pembaruan dan inovasi dalam pemikiran keagamaan. Namun demikian, tidak semua Muslim memiliki pandangan yang sama. Tidak sedikit umat Islam yang justru tidak nyaman dengan pelbagai upaya pembaruan dengan alasan bidah atau memelihara agama dari pemikiran-pemikiran luar. Banyak ulama berpegang pada prinsip "apa yang didiamkan oleh syariat menunjukkan bahwa hukum atas suatu masalah tersebut adalah boleh". Tetapi kebanyakan orang awam memutarbalikkan prinsip tersebut menjadi "apa yang tidak disebutkan dalam syariat adalah hukumnya haram dan melakukannya adalah perbuatan bidah”. Hal yang sama tampaknya juga berlaku pada gagasan-gagasan untuk membentuk

Naskah diterima: 1 Maret 2013, direvisi: 10 Juni 2013, disetujui untuk terbit: 14 Juni 2013. dasar-dasar fikih minoritas Muslim (fiqh al-aqaliyyât) di seluruh dunia.

Meski tergolong baru, secara konseptual fikih minoritas sejatinya bukan model fikih yang benar-benar baru dan terpisah dari fikih tradisional. Fikih minoritas hanyalah satu cabang dari disiplin ilmu fikih yang luas dalam Islam. Ia juga menggunakan metodologi usul fikih yang hampir sama dengan fikih lainya. Karena ia merujuk pada sumber yang sama, yaitu Alquran, Sunah, ijmak, dan kiyas. Oleh karena itu, diperlukan penjelasan yang komprehensif terhadap masalah ini.

Artikel singkat ini akan membahas terminologi fikih minoritas, latar belakang munculnya, para pendiri, dan produk fatwa yang terdapat dalam fikih minoritas.

\section{Terminologi Fiqh al-Aqaliyyât}

Fiqh al-aqaliyyât-yang diterjemahkan ke dalam bahasa Indonesia menjadi "fikih minoritas", terdiri 
atas dua kata: fiqh dan aqalliyyah. Kata fiqh, secara etimologis berarti "paham yang mendalam". Secara terminologis, fikih berarti ilmu tentang hukum-hukum syarak yang bersifat 'amaliyyah atau praktis yang digali dan ditemukan dari dalil-dalil yang terperinci. Kata "amaliyyah" yang terdapat dalam definisi tersebut menjelaskan bahwa fikih itu hanya menyangkut tindak-tanduk manusia yang bersifat lahiriah. Dengan demikian, hal-hal yang bersifat bukan lahiriah, seperti masalah keimanan atau akidah tidak termasuk dalam ruang lingkup fikih. ${ }^{1}$ Kata "aqalliyyah" berasal dari kata qallala yang berarti sedikit, lawan dari banyak. Kata al-qul lawan dari banyak, dan kata qawm-un qalîlu-n berarti sedikit jumlahnya dan lemah fisiknya. ${ }^{2}$ Tâhâ Jâbir al'Alwânî menyatakan bahwa secara etimologis, aqalliyyah bermakna minoritas atau kelompok, merupakan istilah politik yang didefinisikan sebagai kelompok masyarakat dalam suatu pemerintahan yang dalam hal etnis, bahasa, ras, atau agama berbeda dengan kelompok mayoritas yang berkembang. ${ }^{3}$ Menurut Kamal Sa’id Habib, minoritas sebagai sebuah istilah kontemporer tidak dikenal oleh budaya Islam, sebagaimana pengertian yang dipahami oleh istilah sosiologi sekarang. Tetapi karena telah tersebar luas, maka diterima dan dikembalikan bentuk dan definisinya sesuai dengan budaya Islam. ${ }^{4}$

Secara terminologis, fiqh al-aqaliyyât ialah bentuk fikih yang memelihara keterkaitan hukum syarak dengan dimensi-dimensi suatu komunitas dan dengan tempat di mana mereka tinggal. Fikih ini merupakan fikih komunitas terbatas yang memiliki kondisi khusus yang memungkinkan sesuatu yang tidak sesuai bagi orang lain menjadi sesuai bagi mereka. Cara memperolehnya membutuhkan aplikasi sebagian ilmu kemasyarakatan secara umum dan ilmu sosiologi, ekonomi, dan beberapa ilmu politik dan hubungan internasional secara khusus. ${ }^{5}$

Jamâl al-Dîn 'Ațiyyah Muhammad menyatakan, walaupun agak sulit mencari definisi yang bisa diterima semua pihak serta mencakup seluruh bentuk minoritas di dunia yang membutuhkan perlindungan khusus itu, namun terdapat karakter umum kaum minoritas, yakni: kumpulan etnis, grup, agama, bahasa, yang berbeda

${ }^{1}$ Amir Syarifuddin, Ushul Fiqh, (Jakarta: Logos Wacana Ilmu, 1997), h. 2-3.

${ }^{2}$ Ibn al-Manzûr al-Ifrị̂̂î, Lisân al-'Arab, juz V, (al-Qâhirah: Dâr al-Ma'ârif, t.th), h. 2726.

${ }^{3}$ Tâhâ Jâbir al-'Alwânî, Maqâsisid al-Sharî‘ ah, (Bayrût: Dâr al-Hâdî, 2001), h. 95-96.

${ }^{4}$ Kamâl Sa'id Habib, Kaum Minoritas \& Politik Negara Islam Sejak Awal Pemerintahan Nabi SAW Sampai Akhir Pemerintahan Utsman (1H-1325 H atau 621 M-1908 M), (Bogor: Pustaka Thariqul Izzah, 2001), h. 55.

${ }^{5}$ Tâhâ Jâbir al-'Alwânî, Maqâssid al-Sharî‘ah, h. 97. dengan komunitas lain dalam sebuah negara. Ada standar lain yang mengakomodasikan seluruh bentuk minoritas, yakni: Pertama, dari segi jumlah: sudah jelas bahwa kaum minoritas itu jumlahnya harus lebih sedikit dari keseluruhan penduduk yang mayoritas. Kedua, dari segi ketidakberdayaan: kaum minoritas harus tidak memiliki daya dan kekuasaan sehingga membutuhkan perlindungan. Ketiga, perbedaan identitas grup, etnis, budaya, bahasa, dan agama. Kaum minoritas biasanya memiliki ciri khas atau identitas tersendiri seperti: kebangsaan, agama, atau bahasa yang berbeda dengan penduduk mayoritas di suatu negara. ${ }^{6}$

Jadi, fiqh al-aqaliyyât merupakan salah satu jenis fikih yang merupakan bagian dari fikih pada umumnya, hanya saja ia memiliki karakter khusus karena akan diterapkan pada masyarakat dengan karakter khusus, yang berbeda dengan fikih pada umumnya, yakni minoritas Muslim di Barat. ${ }^{7}$ Dari sisi sumber hukum, fiqh al-aqaliyyât sama dengan fikih pada umumnya, yakni bersumber pada Alquran dan Hadis, yang dibangun berdasarkan ijmak, qiyâs, istihbsân, al-masâalih $\underline{b}$ al-mursalah, sad al-dhara'̂, urf, dan dalil-dalil lain yang telah disampaikan oleh para ulama usul fikih. Akan tetapi, dari sisi bentuk fiqh al-aqaliyyât merupakan bentuk yang baru karena pelaku hukumnya adalah masyarakat minoritas Muslim yang memiliki karakter khusus, yang tidak dimiliki oleh mayoritas Muslim lainnya.

Fikih minoritas di seluruh belahan dunia, khususnya dunia Barat, memiliki beberapa tujuan yang hendak direalisasikan dalam kehidupan minoritas dengan berdasarkan pada hukum-hukum syariah dan kaidahkaidahnya. Pertama, fikih ini diharapkan dapat membantu kaum minoritas Muslim: individu, keluarga, dan masyarakat, untuk menghidupkan agama mereka dengan kehidupan yang mudah, tanpa dipersulit dalam mengamalkan agama, sehingga tidak melelahkan mereka dalam menjalankan kepentingan dunia.

Kedua, fikih ini diharapkan dapat menjaga esensi kepribadian Muslim yang baik lengkap dengan akidah, syariah, nilai-nilai, akhlak, moral, dan pemahaman

${ }^{6}$ Jamâl al-Dîn 'Atiyah Muhammad, nạhwa Fiqh Jadîd li alAqaliyyât, Terjemahan oleh Shofiyullah, Fiqh Baru bagi Kaum Minoritas, (Bandung: Marja, 2003), h. 16-18.

Penjelasan mengenai minoritas Muslim di Barat dapat dibaca dalam buku Muslim Minorities in the World Today. Buku ini menjelaskan bagaimana jumlah dan peranan minoritas Muslim di negara Eropah, Amerika, termasuk juga di Asia dan lain-lain. M. Ali Kettani, Muslim Minorities In The World Today, diterjemahkan oleh Zarkawi Soejoeti, Minoritas Muslim di Dunia Dewasa Ini, (Jakarta: RajaGrafindo Persada, 2005). 
universal, sehingga salat, pengorbanan, hidup, dan mati hanya mereka persembahkan untuk Allah semata.

Ketiga, fikih ini diharapkan dapat membantu minoritas melaksanakan kewajiban menyampaikan Islam yang universal bagi kalangan non-Muslim yang hidup di sekitar mereka, dengan bahasa yang dapat dipahami mereka.

Keempat, dapat memberikan sumbangan pemikiran terhadap kalangan minoritas dengan nilai-nilai toleran dan keterbukaan, sehingga tidak terkesan mengisolasikan fikih dari dasar-dasarnya dan tidak menjadikan mereka mengasingkan diri dari masyarakat sosialnya.

Kelima, dapat memberikan sumbangsih dalam mendidik dan menyadarkan Muslim dengan menjaga hak-hak, kebebasan mereka dalam beragama, budaya, sosial, ekonomi, dan politik yang telah dilindungi secara undang-undang. Dan memudahkan dalam menjalankan kewajiban-kewajiban mereka. Keenam, mampu menjawab pelbagai pertanyaaan yang dilontarkan kalangan minoritas. ${ }^{8}$

Tujuan-tujuan tersebut di atas, menunjukkan bahwa Islam bukan hanya untuk negara atau satu wilayah tertentu, tapi untuk seluruh wilayah dan negara di dunia ini. Islam tidak memandang dan menerapkan suatu mazhab tertentu dalam menyelesaikan pelbagai permasalahan yang dihadapi kaum Muslim minoritas dan mayoritas tapi dengan pelbagai pemahaman yang universal agar umat Islam dapat dengan mudah menyesuaikan diri dengan keadaan dan lingkungan mereka.

\section{Latar Sosial Fikih Minoritas}

Fiqh al-aqaliyyât merupakan satu doktrin hukum yang diperkenalkan pada 1990-an. Doktrin ini menegaskan bahwa kaum minoritas Muslim, terutama yang bermukim di Barat, berhak mendapatkan disiplin ilmu hukum khusus untuk menjawab kebutuhan keagamaan mereka yang khas, bahkan mungkin unik. Al-'Alwânî memperkenalkan fiqh al-aqaliyyât dan menggunakannya untuk kali pertama pada 1994 ketika Majelis Fikih Amerika Utara, di bawah kepemimpinannya, mengeluarkan fatwa (pendapat hukum) mengizinkan orangorang Muslim Amerika untuk memberikan suara dalam pemilihan umum di negeri adi kuasa tersebut, meskipun tidak ada partai politik Islam, atau bahkan kosong sama sekali dari kandidat Muslim. ${ }^{?}$

${ }^{8}$ Yûsuf al-Qarâdawî, Fî Fiqh al-aqaliyyât al-Muslimah, terjemah oleh Adillah Obid, Fiqh Minoritas: Fatwa Kontemporer terhadap Kehidupan Kaum Muslimin di Tengah Masyarakat Non Muslim, (Jakarta: Zikrul Hakim, 2004), h. 36-38.

${ }^{9}$ Muhammad Khalid Mas'ud, 'Islamic Law and Muslim Minorities,'
Kehadiran fiqh al-aqaliyyât ini sejatinya berawal dari akumulasi kegelisahan masyarakat minoritas Muslim di Barat ketika harus melakukan sesuatu yang berkaitan dengan keagamaan mereka. Di satu sisi, mereka harus taat pada ajaran agama yang diyakini sempurna (al-Mầidah [5]: 3) dan dipilih oleh Allah sebagai panduan yang sesuai dengan fitrah manusia dalam menemukan kedamaian di dunia dan akhirat (al-Rûm [30]: 30), sementara di sisi lain ada ketidaksesuaian antara ketentuan-ketentuan fikih klasik yang mereka pahami dan realitas sosial budaya di tempat mereka tinggal. Bagi mereka, kenyataan ini berarti bahwa melaksanakan ajaran agama yang mereka pahami akan menjadikan mereka teralienasi dari lingkungan, sementara meninggalkan ajaran agama merupakan sesuatu yang tidak pernah dibayangkan. Dari sini muncul pertanyaan tentang klaim universalitas Islam yang menyatakan bahwa segala aspek keislaman, baik yang berhubungan dengan akidah, syariah, maupun akhlak merupakan perwujudan rahmat Allah yang bersifat universal bagi semua hamba-Nya.

Idealnya, umat Islam hidup sesuai dengan panduan syariah sebagai terhimpun dalam fikih (yurisprudensi). Namun, permasalahan yang muncul kemudian adalah ketika hukum Islam yang mereka pahami tidak lagi bersifat adaptable dan memudahkan sebagai pegangan hidup di negara Barat, tempat di mana mereka hidup dan mencari penghidupan. Sulitnya penerapan fikih klasik dalam konteks ini melahirkan dua opsi ketika mereka harus tetap bertahan sebagai Muslim yang baik. Pertama, keluar dari negara Barat dan kembali ke negara asal di mana hukum Islam yang mereka pahami bisa dijalankan dengan mudah. Kedua, melakukan reinterpretasi hukum Islam itu sendiri atas dasar keberanian dan semangat bahwa Islam itu memang sesuai dengan semua tempat dan waktu serta legal maxim (kaidah hukum) bahwa hukum Islam itu bisa berubah sesuai dengan perubahan waktu dan tempat dan bahwa eksistensi hukum itu tergantung illa ${ }^{10}$-nya.

Terlepas dari perbedaan pendapat tersebut di atas, minoritas Muslim yang tinggal di negara-negara Barat adalah kenyataan yang semakin lama semakin ber-

\footnotetext{
dalam ISIM Review, No. 11, (2002), h. 17.

10 'Illah menurut bahasa berarti "sesuatu yang bisa mengubah keadaan", misalnya penyakit disebut 'illah karena sifatnya mengubah kondisi seseorang yang terkena penyakit itu. Menurut istilah, 'illah adalah suatu sifat yang konkret yang dapat dipastikan keberadaannya pada setiap pelakunya dan menurut sifatnya sejalan dengan tujuan pembentukan suatu hukum, yaitu mewujudkan kemaslahatan dengan meraih kemanfaatan dan menolak kemudaratan dari umat manusia. Satria Effendi, Ushul Fiqh, (Jakarta: Kencana, 2005), h. 135.
} 
kembang. Mereka telah hidup bertahun-tahun dari satu generasi ke generasi berikutnya. Problematika yang mereka hadapi menjadi unik bukan hanya karena perbedaan waktu, cuaca, dan musim yang bisa jadi berimplikasi pada kesulitan pengaturan jadual ibadah, melainkan juga karena perbedaan kebijakan hidup berbangsa dan bernegara yang mengharuskan adanya dialog, proses adaptasi, ataupun asimilasi.

Problematika modernitas yang dihadapi oleh minoritas Muslim di Barat dan kondisi psiko-sosial yang dirasakan mereka tidak mampu dibayangkan dan dirasakan oleh para fukaha klasik. Fikih klasik tidak mampu secara jelas dan tegas menjawab persoalanpersoalan hukum Islam yang mereka hadapi, karena fikih klasik ditulis pada masa lampau di wilayah yang mayoritas penduduknya adalah Muslim. Oleh karena itu, para sarjana kontemporer yang peduli dan bahkan juga tinggal sebagai minoritas di negara Barat berupaya melakukan reinterpretasi atas nas hukum yang ada dengan piranti ijtihad yang terus digalakkkan dalam upaya menemukan bentuk fikih yang mampu menjawab persoalan masyarakat minoritas Muslim di Barat. Dari upaya ini, melatarbelakangi lahirnya fiqh al-aqaliyyât atau fikih minoritas yang sangat diperlukan sebagai panduan hidup bagi kaum minoritas Muslim yang berdomisili di negara Barat.

\section{Pendiri Fikih Minoritas}

Tâhâ Jâbir al-'Alwânî melalui bukunya, Toward a Figh for Minorities: Some Basic Reflections, dan Yûsuf al-Qaradawî dalam Fî Fiqh al-Aqaliyyât al-Muslimah, dianggap sebagai orang yang pertama yang mengenalkan terminologi fiqh al-aqaliyyât. Memang, problematika hukum Islam di kalangan minoritas telah banyak terjadi sebelum istilah fiqh al-aqaliyyât ini muncul, dan pendapat-pendapat hukum untuk masyarakat Muslim minoritas pun banyak dan beragam. Namun, kedua tokoh inilah yang menggagas perlunya suatu bentuk fikih yang khusus dan utuh dari sisi materi dan metodologinya. Gagasan keduanya ini kemudian mendapat tanggapan luas sehingga menjadi diskursus publik, baik dalam bentuk kajian formal organisasi keagamaan maupun kajian akademis di pelbagai perguruan tinggi dan lembaga keilmuan lainnya. Tulisan-tulisan dalam bentuk buku dan artikelpun tentang fiqh al-aqaliyyât mulai banyak diterbitkan, seperti tulisan Bin Bayyah, M. Khalid Mas'ud, Shammai Fishman, Mathias Rohe, dan Wahbah al-Zuhaylî. ${ }^{11}$

\footnotetext{
${ }^{11}$ Ahmad Imam Mawardi, Fiqh Minoritas: Fiqh al-Aqalliyyat dan
}

Tâhâ Jâbir al-'Alwânî adalah sarjana kelahiran Irak pada 1354 H/1935 M. Dia menerima pendidikan dasar dan menengah di tanah kelahirannya dan kemudian lulus dengan gelar kehormatan dari College of Shari'ah dan Hukum di Universitas al-Azhar di Kairo pada 1959. Dari Universitas yang sama beliau dianugerahi gelar Master pada 1968, dan gelar doktornya pada 1973 dalam bidang ilmu usul fikih, disiplin ilmu teori dan metodologi hukum Islam, yang merupakan disiplin ilmu yang paling tepat untuk mengorbitkan seseorang untuk menjadi ahli hukum dan mufti. Sejak 1963 sampai dengan 1969, dia bekerja sebagai imam tentara dan dosen dalam bidang kajian Islam di Akademi Militer Irak. Dari 1975 hingga 1985, ia mengajar mata kuliah hukum Islam di Universitas Ibn Sa’ud di Riyâd, Saudi Arabia. ${ }^{12}$

Selanjutnya dia pindah dari benteng kuat Wahabi ke Amerika Serikat yang bermukim di Virginia, di mana ia melibatkan diri pada sejumlah kegiatan keilmuan. Transisi yang menarik ini merupakan pertanda bagi sikap terbuka al-'Alwânî terhadap Barat, yang tergambar dari ajakannya terhadap orang Islam Amerika untuk "take the best of America society". Dia juga adalah anggota dari Majelis Fikih Internasional (International Figh Council) yang berpusat di Jeddah, yang bertindak sebagai otoritas pusat bagi majelis-majelis fikih, dan ini merupakan bagian dari Organisasi Konferensi Negaranegara Islam (OKI). Selama bertahun-tahun al-'Alwânî telah bekerja sebagai presiden IIIT (International Institute of Islamic Thought) yang memiliki cabang di banyak tempat di dunia, termasuk satu di Jakarta.

Pada 2001, al-Alwânî menerbitkan sebuah buku kecil dalam bahasa Arab yang berjudul Nazariyyah Tasisisiyyah fi Fiqh al-Aqaliyyât (pandangan dasar tentang fikih minoritas). Sejak itu lembaga-lembaga kuat dan website populer telah berkembang, mendukung, dan mendorong doktrin ini. Dia juga merupakan pimpinan Sekolah Pascasarjana Ilmu-ilmu Sosial dan Islami (Islamic and Social Sciences) di Ashburn, Virginia, dan pendiri dan mantan presiden Majelis Fikih Amerika Utara.

Adapun Yûsuf al-Qarâdawî̀r merupakan seorang

Evolusi Maqashid al-Syariah dari Konsep ke Pendekatan, (Yogyakarta: LKis, 2010), h. 116.

${ }^{12} \mathrm{http}: / /$ islamicweb.com/beliefs/fiqh/alawani_usulalfiqh/taha.htm

13 Al-Qaradawî memiliki tujuh orang anak: empat perempuan dan tiga laki-laki. Sebagai seorang ulama yang sangat terbuka, dia membebaskan anak-anaknya untuk menuntut ilmu apa saja sesuai dengan minat dan bakat serta kecendrungan masing-masing. Dan hebatnya lagi, dia tidak membedakan pendidikan yang harus ditempuh anak-anak perempuannya dan anak laki-lakinya. Salah seorang putrinya memperoleh gelar doktor fisika dalam bidang nuklir dari Inggris. Putri keduanya memperoleh gelar doktor dalam bidang kimia juga dari 
cendekiawan Muslim yang berasal dari Mesir dan dikenal sebagai seorang mujtahid pada era modern ini. Beliau lahir di sebuah desa kecil di Mesir bernama Shafth Turaab di tengah Delta Sungai Nil pada 9 September 1926. Usia 10 tahun, ia sudah hafal Alquran. Menamatkan pendidikan di Ma'had Tanta dan Ma'had Thanawi, al-Qarâdawî terus melanjutkan ke Universitas al-Azhar, Fakultas Ushuluddin dan lulus pada 1952. Gelar doktornya baru ia peroleh pada tahun 1972 dengan disertasi "Zakat dan Dampaknya dalam Penanggulangan Kemiskinan", yang kemudian disempurnakan menjadi Fikih Zakat. Sebuah buku yang sangat komprehensif membahas persoalan zakat dengan nuansa modern. ${ }^{14}$

Perkembangan pemikiran al-Qaradawî yang oleh banyak pengamat dinilai mengalami pergeseran dari pemikiran yang konservatif menuju pemikiran yang moderat. Pandangannya yang dahulu tegas dan konservatif dalam penentuan hukum Islam dan dalam menilai pola hubungan Islam dan Barat mulai melunak seiring dengan pengalamannya bertautan langsung dengan dunia Barat. Meskipun demikian, komitmen keislamannya sangat kental terasa dan karena itulah dia berkeyakinan bahwa Islam bisa memberikan jawaban terhadap semua persoalan hidup termasuk apa yang dihadapi oleh masyarakat minoritas Muslim di Barat.

Bukunya yang berjudul lengkap Fî Fiqh al-Aqaliyyât al-Muslimah: Hayâh al-Muslimîn Wasat al-Mujtama'ah al-Ukhrâ berisikan gagasan-gagasannya tentang hukum Islam dalam menjawab persoalan kontemporer minoritas Muslim di Barat. Baginya, persoalan keberagamaan masyarakat minoritas Muslim di Barat tidak bisa dan tidak mungkin diselesaikan dengan cara mengirimkan mereka kembali ke negara-negara Muslim, karena sesungguhnya masalah tersebut bukan terletak pada eksistensi mereka di Barat, melainkan

\footnotetext{
Inggris, sedangkan yang ketiga masih menempuh S-3. Adapun anak yang keempat telah menyelesaikan pendidikan S-1-nya di Universitas Texas Amerika. Anak laki-laki yang pertama menempuh S-3 dalam bidang teknik elektro di Amerika, yang kedua belajar di Universitas Darul Ulum Mesir. Sedangkan yang bungsu telah menyelesaikan kuliahnya pada fakultas teknik jurusan listrik. Dilihat dari beragamnya pendidikan anak-anaknya, dapat diketahui sikap dan pandangan alQarâdawî terhadap pendidikan modern. Dari tujuh anaknya, hanya satu yang belajar di Universitas Darul Ulum Mesir dan menempuh pendidikan agama. Sedangkan yang lainnya, mengambil pendidikan umum dan semuanya ditempuh di luar negeri. Sebabnya karena alQarâdawî merupakan seorang ulama yang menolak pembagian ilmu secara dikotomis. Semua ilmu bisa islami dan tidak islami, tergantung kepada orang yang memandang dan mempergunakannya. Pemisahan ilmu secara dikotomis itu, menurut dia, telah menghambat kemajuan umat Islam. http://media.isnet.org/islam/Qardhawi/Qardhawi.html.

${ }^{14} \mathrm{http} / / /$ id.wikipedia.org/wiki/Yusuf_al-Qaradawi.
}

karena kurang memadainya fikih klasik menjawab permasalahan mereka. Karena itulah, ECFR ${ }^{15}$ yang diketuainya berupaya memberikan fatwa-fatwa baru yang dihasilkan dari penelitian dan reinterpretasi hukum Islam.

Fiqh al-Aqaliyyât sesungguhnya bukanlah sesuatu yang secara total baru dan bukan pula deviasi dari fikih klasik yang ada, melainkan sebuah produk hasil reinterpretasi atas dalil-dalil yang ada atas dasar kemaslahatan yang memang menjadi spirit syariah. Fiqh al-aqaliyyât tampak seperti hal yang baru karena ia dimunculkan di wilayah baru, yakni wilayah Barat. Pada sisi lain, fiqh al-aqaliyyât menjadi bentuk fikih yang saat ini banyak dikenal dan dipahami. Fikih ini didesain untuk memberikan panduan tentang hal-hal yang dilarang dan yang boleh bagi minoritas Muslim yang tinggal di Barat, yang tidak bersistem pemerintahan yang Islami.

\section{Produk Fatwa dalam Fikih Minoritas}

Kalangan minoritas, baik penduduk asli atau migran, memiliki banyak persoalan yang telah dikeluhkan. Di antara persoalan tersebut terdapat dalam bidang politik, yang disebabkan oleh ketidakadilan kaum mayoritas dalam memberikan hak-hak mereka, dan tidak adanya perhatian kaum mayoritas terhadap privasi agama mereka (kebebasan pribadi dalam berakidah dan dalam melaksanakan ritualitas ajaran agamanya). Persoalan lain berkaitan dengan masalah ekonomi. Sebagian besar kalangan minoritas itu dari fakir miskin dan masyarakat yang memiliki pemasukan (income) terbatas, di mana kaum mayoritas yang berkuasa telah bertindak sewenang-wenang terhadap pelbagai potensi dan harta mereka.

Sebagian lain juga berkaitan dengan masalah budaya, bersumber dari dominasi budaya mayoritas terhadap pendidikan, informasi, pusat-pusat penyuluhan, dan kehidupan umum, yang cenderung menafikan kebudayaan kaum muslimin dalam menerapkan akidah, nilai-nilai, dan identitas diri.

Dalam bidang hukum keluarga, misalnya, ada

15 ECFR atau dalam bahasa Arab dikenal dengan al-Majlis alUrûbî li al-Ifta' wa al-Buhûth didirikan oleh 15 sarjana Muslim di London pada tanggal 29-30 Maret 1997 dengan mengangkat Yûsuf al-Qarâdawî sebagai ketua. Tujuan lembaga ini adalah memberikan saran dan fatwa kepada al-Mustaghrabûn, imigran Muslim di Barat berkenaan dengan problematika hukum yang dihadapi sehingga mereka memiliki pandangan yang seragam dan tidak dibingungkan lagi dengan perbedaan pendapat para fukaha yang sangat banyak dan beragam. Ahmad Imam Mawardi, Fiqh Minoritas: Fiqh al-Aqalliyyât dan Evolusi Maqashid al-Syariah dari konsep ke Pendekatan, h. 103. 
seorang laki-laki yang baru masuk Islam (mualaf) yang ditinggal mati oleh kedua orang tuanya yang masih tetap beragama non-Islam. Orang tuanya meninggalkan harta yang sangat banyak dan berlimpah ruah. Apakah dia boleh menerima harta orang tuanya tersebut? Sesungguhnya orang yang hanya berkiblat kepada keempat mazhab terkenal menurut Abl al-Sunnah, bahkan yang membaca mazhab yang tujuh atau delapan (ditambah dengan mazhab Ja'fariyyah, Zaydiyyah, 'Ibâdiyyah, dan zahiriyyah) akan menemukan bahwa perbedaan agama telah menjadikan warisan tersebut sebagai larangan dari pelbagai larangan warisan yang terkenal. Mereka bersandarkan diri dalam hal warisan ini kepada Hadis Nabi yang cukup masyhur, "Orang muslim itu tidak dapat mewarisi harta orang kafir dan orang kafir tidak dapat mewarisi harta orang muslim." Dalam Hadis yang lain disebutkan, "Tidak ada hak saling mewarisi antara dua orang pemeluk agama yang berbeda-beda." Akan tetapi, orang yang membahas di luar empat mazhab akan menemukan pendapat yang mu'tabar yang memperbolehkan warisan seorang Muslim dari seorang kafir. Pendapat tersebut telah dikatakan oleh sebagian ulama dari kalangan Sahabat dan Tabi'in. Telah diriwayatkan dari Mu'adh ibn Jabal, Mu'âwiyah ibn Abi Sofyan, dari kalangan sahabat Nabi, sebagaimana juga telah diriwayatkan dari Muhammad

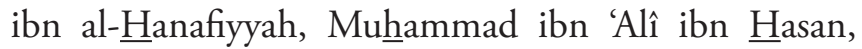
Sa'îd ibn Musayyab, Masrûq ibn Ajda', 'Abd Allah ibn Mughaffal, Yahyâ ibn Ya’mar, dan Ishâq ibn Rahawayh.

Shaykh al-Islâm, Ibn Taymiyyah dan muridnya, sang pen-tahqî $q$, Ibn Qayyim telah membenarkan pendapat ini. Hal tersebut merupakan tarjih yang sangat berharga dan bernilai pada zaman kita sekarang. Dan keduanya adalah ulama yang kali pertama berpendapat tentang 'kafir' dalam Hadis "Orang Muslim tidak dapat mewarisi harta orang kafir", bahwa yang dimaksudkan dengan Hadis tersebut adalah "kafir $\underline{h} a r b \hat{\imath}$ " seperti segolongan ulama yang menyatakan Hadis, "Seorang Muslim tidak boleh dibunuh hanya karena membunuh orang kafir" adalah untuk kafir harbî. Ibn Qayyim berkata, "Dan dikaitkannya terhadap al- $\underline{h} a r b \hat{\imath}$ (orang yang memusuhi kaum muslimin) dalam konteks ini adalah lebih utama dan lebih dekat perkiraan. ${ }^{16}$

Lebih lanjut al-Qarâdawî menyatakan bahwa dimensi kemaslahatan menerima warisan non-Muslim akan lebih besar daripada membiarkan harta waris itu dikuasai umat non-Muslim yang kemungkinan akan dipergunakan untuk kepentingan maksiat atau

\footnotetext{
${ }^{16}$ Yûsuf al-Qaradawî, Fî̀ Fiqh al-Aqaliyyât al-Muslimah, h. 76-77.
}

pengembangan agama mereka. Untuk tidak terkesan menentang derajat sahih dari Hadis tentang larangan saling mewarisi antara orang Islam dan orang nonmuslim tersebut di atas, al-Qarâdawî melakukan takwil

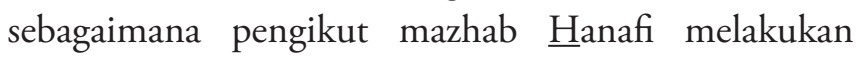
takwil pada Hadis, "Seorang Muslim tidak boleh dibunuh hanya karena membunuh orang kafir." Menurut mereka, orang kafir yang dimaksudkan sebagaimana yang telah dijelaskan di atas adalah orang kafir $\underline{h} a r b \hat{\imath}$ yang memerangi Islam. Oleh karena itu, larangan saling mewarisi juga berlaku hanya antara Muslim dan kafir harbî.

Dalam bidang politik, seperti bagaimanakah hukum ikut serta dalam masalah politik dan memilih pemimpin negara yang bukan Muslim di negara Barat, sebab syarat menjadi pemimpin menurut fikih klasik sangat ketat meliputi masalah agama, kepribadian, keilmuan, dan lain sebagainya. ${ }^{17}$ Atas permasalahan ini EFCR memberikan beberapa pandangan hukum. Pertama, tujuan kerja sama atau ikut serta dalam politik adalah untuk menjaga hak, kebebasan, dan mempertahankan nilainilai diri serta eksistensi umat Islam di negara tersebut. Kedua, hukum asal menentukan disyariatkannya kerja sama politik bagi umat Islam di negara Barat, dengan status hukum boleh, sunah, dan wajib atas dasar ayat Alquran surah al-Mầidah [5] ayat 2. Ketiga, kerja sama politik meliputi menjadi anggota lembaga sosial kemasyarakatan, ikut serta dalam partai politik, dan lain sebagainya. Keempat, termasuk kaidah yang paling penting yang harus dipegang dalam kerja sama politik ini adalah tetap berpegang teguh pada akhlak islami, seperti kejujuran, keadilan, dan tanggung jawab, serta menghargai pluralisme dan pandangan yang berbeda. Kelima, ikut serta dalam pemilihan umum dengan syarat berpegang pada kaidah-kaidah syariat, etika, dan perundang-undangan, dengan niat kemaslahatan dan tidak didasarkan pada kepentingan individu. Keenam, bolehnya menggunakan harta benda untuk kepentingan pemilihan umum tersebut walaupun yang dipilih bukan seorang muslim, sepanjang dipandang mampu mewujudkan kemaslahatan umum. Ketujuh, kebolehan kerja sama politik tersebut berlaku sama bagi perempuan Muslimah sebagaimana berlaku bagi laki-laki. Pandangan EFCR di atas lebih menekankan pada konteks dan berorientasi pada kemaslahatan, yang merupakan inti dari maqâsid al-sharîah.

Bidang akidah dan ibadah, seperti bagaimanakah hukum menguburkan jenazah Muslim di pemakaman

${ }^{17}$ Abû Hasan al-Mâwardî, Al-A $\underline{\text { H} k a m}$ al-Sultâniyyah, (Bayrût: Dâr al-Kitâb al-'Arabî, 1990), h. 31-32. 
orang-orang Nasrani, karena tidak ada pemakaman khusus bagi orang-orang muslim. Atau, ada pemakaman khusus Muslim, tetapi tempatnya sangat jauh dari keluarga si mayat, sehingga sulit bagi mereka untuk menziarahinya sewaktu-waktu. Al-Qarâdhawî menyatakan, apabila kalangan Muslim tidak mampu untuk mewujudkan pemakaman khusus tersebut, maka paling tidak dialokasikannya sebidang tanah bagi orang-orang Muslim di pemakaman Nasrani, sehingga mereka dapat menguburkan jenazah Muslim di sebidang tanah tersebut.

Namun, apabila tidak ada kemudahan bagi kaum Muslimin, baik di suatu tempat atau di tempat lainnya, kemudian salah satu dari anggota keluarga mereka meninggal dunia, maka hendaknya-jika terdapat kemudahan untuk itu-mereka memindahkan mayat tersebut ke kota lain yang terdapat di dalamnya pemakaman khusus kaum muslimin. Jika tidak ada, hendaknya mereka menguburkannya di pemakaman Nasrani sesuai dengan kemampuan mereka dengan bersandarkan pada hukum-hukum darurat. Sesungguhnya Allah Swt. tidak membebani seseorang melainkan sesuai dengan kesanggupannya. Dan sama sekali tidak akan menyesatkan bagi seorang Muslim yang salih apabila meninggal dunia, lalu ia dikuburkan di pemakaman non-Muslim dalam kondisi yang seperti ini. Sebenarnya, yang bermanfaat bagi seorang Muslim di akhiratnya adalah usaha dan amal salihnya, bukan tempat pemakamannya. Allah Swt. berfirman yang artinya, "Dan bahwasanya seorang manusia tiada memperoleh selain apa yang telah diusahakannya." (Q.s. al-Najm [53]: 39).

Namun demikian, jauhnya pemakaman dari keluarga si mayat bukan berarti memperbolehkan menguburkan mayat Muslim di pemakaman nonMuslim. Karena, menguburkan jenazah Muslim di pemakaman kaum muslimin hukumnya adalah wajib, sebagaimana telah disepakati mayoritas para ulama. Sedangkan menziarahi mayit (kuburan) hukumnya adalah sunah. Maka dari itu, tidak diperbolehkan untuk menghilangkan perkara yang wajib hanya untuk memenuhi perkara yang bersifat sunah. Karena pada dasarnya disyariatkan menziarahi kuburan hanya untuk kemaslahatan peziarah. Yaitu, agar dirinya dapat mengambil pelajaran dari kematian, sebagaimana yang telah diterangkan dalam sebuah Hadis, "Sesungguhnya aku pernah melarang kalian untuk menziarahi kuburan, maka ziarahilah (kuburan), sesungguhnya hal tersebut akan menenangkan hati, meneteskan air mata, dan mengingatkan kepada akhirat." Sedangkan bagi mayit, seorang Muslim dapat mendoakannya dan memohonkan ampun baginya, di mana pahalanya akan sampai kepada si mayit tersebut dengan kekuasaan Allah Swt., walaupun orang yang memanjatkan doa tersebut berada di pelbagai tempat.

Masalah-masalah di atas adalah beberapa fatwa tentang fikih minoritas dan masih banyak masalah lain yang tidak dapat penulis kemukakan dalam artikel ini. Dari beberapa fatwa tersebut, dapat diketahui bahwa maqâsid al-sharî́ah dalam fikih ini lebih diposisikan sebagai metode pendekatan ketimbang sebagai konsep nilai yang agung, seperti umumnya dalam fikih tradisional. Produk hukumnya pun berbeda. Kalau dalam fikih pada umumnya, produk hukum didasarkan pada hujjiyah al-nass (otoritas nas), maka produk hukum dalam fiqh al-aqaliyyât didasarkan pada bujjiyah al-maqâsid (kekuatan nilai-nilai tujuan syarak), yaitu untuk mendapatkan kemaslahatan dan menghilangkan kemudaratan.

Dengan demikian, konsekuensi logisnya adalah bahwa fiqh al-aqaliyyât membebaskan diri dari perbedaan mazhab dan berhak memilih pendapat dari mazhab manapun yang dianggap lebih mencerminkan realisasi kemaslahatan ketika masalah hukum yang terjadi memiliki padanan dengan atau pernah dibahas pada masa lalu. Dalam kasus-kasus baru, pertimbangan realisasi maqashid al-sharî‘ah sebagai prinsip dan nilai universal Islam mengungguli dominasi teks sebagaimana terjadi dalam kajian fikih pada umumnya.

\section{Penutup}

Fiqhal-aqaliyyât adalah bentuk fikih baru yang dibuat secara khusus untuk menjawab persoalan-persoalan kehidupan beragama yang dihadapi oleh masyarakat minoritas Muslim di Barat. Fikih ini diperlakukan sebagai sebuah sistem yang mempersatukan masyarakat minoritas Muslim di Barat. Fiqh al-aqaliyyât digagas oleh Tâhâ Jâbir al-'Alwânî dan Yûsuf al-Qaradawîi.

Fiqh al-aqaliyyât tidak lain sebagai sekumpulan ajaran Islam yang dianggap mampu mengakomodasi persoalan-persoalan kontemporer yang dihadapi oleh kalangan minoritas Muslim dalam menjalankan ajaran agamanya. Walaupun fikih ini dikemas dalam format yang berbeda dari format hukum Islam pada umumnya, akan tetapi ia tetaplah berakar dan tidak melenceng dari prinsip-prinsip dasar ajaran agama Islam.

Fiqh al-aqaliyyât berfungsi sebagai pegangan bagi minoritas Muslim dalam melaksanakan ajaran agamanya, bukan hanya sebagai individu, melainkan juga sebagai masyarakat secara umum. Fikih ini memberikan 
panduan bagaimana mereka berinteraksi dengan agama lainnya, sehingga agama Islam yang dianutnya bukan sebagai dinding pemisah, tetapi menjadi jembatan penghubung antarmereka. Karena Islam menganut nilai-nilai yang universal, cinta dan kasih sayang, ta'âruf (saling mengenal), keadilan, serta menghormati hakhak asasi manusia, sehingga hal ini akan mempermudah kehidupan keberagamaan mereka.[]

\section{Pustaka Acuan \\ Buku:}

'Alwânî, al-, Thâhâ Jâbir, Maqâsidi al-Sharî‘ah, Bayrût: Dâr al-Hâdî, 2001.

Effendi M. Zein, Satria, Usul Figh, Jakarta: Kencana, 2005.

Habib, Kamal Sa’id, Kaum Minoritas \& Politik Negara Islam Sejak Awal Pemerintahan Nabi SAW Sampai Akhir Pemerintahan Utsman (1H-1325H atau 621 M-1908 M), Bogor: Pustaka Thariqul Izzah, 2001.

Ibn al-Manzû̂r al-Ifrî̀î, Lisân al-'Arab, al-Qâhirah: Dâr al-Maârif, t.th.

Kettani, M. Ali, Muslim Minorities in the World Today, Terjemahan oleh Zarkowi Soejoeti, Minoritas Muslim di Dunia Dewasa Ini, Jakarta: RajaGrafindo Persada, 2005.
Mas'ud, Muhammad Khalid, 'Islamic Law and Muslim Minorities,' dalam ISIM Review, No. 11, (2002).

Mawardi, Ahmad Imam, Fikih Minoritas: Figh al'Aqalliyyah dan Evolusi Maqashid al-Syariah dari Konsep ke Pendekatan, Yogyakarta: LKis, 2010.

Mâwardî, al-, Abû Hasan, Al-A $\underline{h} k \hat{a} m$ al-Sultâniyyah, Bayrût: Dâr al-Kitâb al-'Arabî, 1990.

Muhammad, Jamaluddin Athiyah, Naḥw Figh Jadîd lil Aqaliyyah, terjemahan Shofiyullah, Fiqh Baru bagi Kaum Minoritas, Bandung: Marja, 2003.

Qaradawî, al-, Yûsuf, Fî Figh al-Aqalliyyât al-Muslimah: Hayâh al-Muslimîn Wasat al-Mujtama'ah al-Ukhrâ, terjemahan Adillah Obid, Fikih Minoritas Muslim: Fatwa Kontemporer Terhadap Kehidupan Kaum Muslimin di Tengah Masyarakat Non Muslim, Jakarta: Zikrul Hakim, 2004.

Syarifuddin, Amir, Ushul Figh, Jakarta: Logos Wacana Ilmu, 1997.

\section{Website:}

http://islamicweb.com/beliefs/fikih/alawani_ usulalfikih/taha.htm.

http://media.isnet.org/islam/Qardhawi/Qardhawi. html.

http://id.wikipedia.org/wiki/Yusuf_al-Qaradawi. 